SOILS AND OTHER GROWTH MEDIA 


\section{Science in Horticulture Series}

General Editor: Professor L. Broadbent, University of Bath

Published in collaboration with the Royal Horticultural Society and the Horticultural Education Association.

This series of texts has been designed for students on courses in horticulture at the Higher National Certificate or Diploma level, but care has been taken to ensure that they are not too specialised for lower-level courses, nor too superficial for university work.

All the contributors to the series have had experience in both the horticultural industry and education. Consequently, the books have a strong practical flavour which should reinforce their value as textbooks and also make them of interest to a wide audience, including growers and farmers, extension officers, research workers, workers in the agrochemical, marketing and allied industries, and the many gardeners who are interested in the science behind their hobby.

The authors are all British, but they have illustrated their books with examples drawn from many countries. As a result the texts should be of value to English-speaking students of horticulture throughout the world. 


\title{
SOILS AND OTHER GROWTH MEDIA
}

\author{
A. W. Flegmann, M A, PhD \\ Raymond A. T. George, BSc, NDH, MIBiol \\ Lecturers in the School of Biological Sciences, \\ University of Bath
}

\section{M}




\title{
ISBN 978-1-349-01208-4 ISBN 978-1-349-01206-0 (eBook) DOI 10.1007/978-1-349-01206-0
}

(C) A. W. Flegmann and Raymond A. T. George 1975

All rights reserved. No part of this publication may be reproduced or transmitted, in any form or by any means, without permission.

\author{
First published 1975 by \\ THE MACMILLAN PRESS LTD \\ London and Basingstoke \\ Associated companies in New York Dublin \\ Melbourne Johannesburg and Madras
}

SBN 333125711

Set I.B.M. by

GEORGE OVER LIMITED, LONDON AND RUGBY

\begin{abstract}
The paperback edition of this book is sold subject to condition that it shall not, by way of trade or otherwise, be lent, re-sold, hired out, or otherwise circulated without the publisher's prior consent in any form of binding or cover other than that in which it is published and without a similar condition including this condition being imposed on the subsequent purchaser.
\end{abstract}




\section{CONTENTS}

Preface

vii
PART I
BASIC PRINCIPLES
A. W. Flegmann

1. Microstructure of Soil Materials

1.1 The Role of Soil Particle Surfaces and of the Soil Pore Space

1.2 Microcrystalline Inorganic Soil Materials 7

Clay mineral structures $\quad 7$

Electrically charged sites on clay mineral surfaces $\quad 12$

$\begin{array}{ll}\text { lon exchange on clay minerals } & 15\end{array}$

Flocculation and coagulation $\quad 20$

The nature of water at clay surfaces 24

1.3 Amorphous Inorganic Soil Materials 26

1.4 Organic Soil Materials 28

1.5 Clay-Organic Complexes $\quad 32$

Summary $\quad 35$

2. The Molecular Environment of Plant Roots 37

2.1 The Forces of Water Retention in Soils 37

2.2 The Free Energy of Soil Water 44

2.3 The Soil Moisture Characteristic Curve and Soil

2.4 The Flow of Soil Water 52

2.5 Infiltration and Drainage 56

2.6 Soil Water Measurements: Amounts and Tensions 59

2.7 Soil Aeration $\quad 65$

$\begin{array}{ll}\text { Summary } & 69\end{array}$

3. The Ionic Environment of Plant Roots 71

3.1 Cation Equilibria in Soils 72

$\begin{array}{ll}\text { Cation exchange } & 72\end{array}$

$\begin{array}{ll}\text { Cation fixation } & 75\end{array}$

$\begin{array}{ll}\text { Soil acidity } & 78\end{array}$

Soil salinity $\quad 80$

3.2 Soil-Anion Interactions $\quad 83$

3.3 Movement of lons in Soils 90

$\begin{array}{ll}\text { 3.4 Characterization of Plant Nutrient Supply } & 92\end{array}$

Summary $\quad 97$ 
PART II HORTICULTURAL PRINCIPLES Raymond A. T. George

4. Macroscopic Structure and Properties of Growth Media 101

$\begin{array}{lll}4.1 \text { Field Soils } & 101\end{array}$

$\begin{array}{ll}\text { Profiles } & 102\end{array}$

Horizons $\quad 103$

Drainage 104

Soil texture 105

Field assessment of soils $\quad 105$

Soil structure 105

4.2 Container Media 108

Requirements of satisfactory media $\quad 109$

Loam-based composts $\quad 110$

Loamless composts $\quad 111$

The U.C. mixes 111

G.C.R.I. compost 112

Peat composts $\quad 112$

Straw substrates $\quad 112$

Summary 113

5. The Management of Soils for Horticultural Crops 114

5.1 Control of Physical Properties $\quad 114$

Cultivation $\quad 114$

Compaction $\quad 117$

Rainfall and irrigation $\quad 117$

$\begin{array}{ll}\text { Drainage } & 118\end{array}$

Rotations and break crops $\quad 118$

$\begin{array}{ll}\text { Mulching } & 120\end{array}$

Noncultivation systems $\quad 123$

5.2 Control of Chemical Properties 123

Crop nutrition $\quad 123$

Liming $\quad 127$

The role of nutrients in plant growth and their

5.3 Maintenance of Physical Properties $\quad 141$

Organic additives $\quad 141$

Mineral additives $\quad 145$

Chemical additives 146

5.4 Control of Biological Properties 146

Range of organisms in growth media $\quad 146$

Undesirable biological constituents $\quad 147$

Methods of control 148

Bibliography $\quad 155$

Glossary 159

Table of SI Units $\quad 163$

Index 165 


\section{PREFACE}

It is well established that plants can be raised to maturity without the assistance of soils, yet most plants are (and will be for the foreseeable future) grown on soils or similar growth media. A good understanding of the basic physical and chemical principles underlying the soil processes that contribute to plant growth facilitates the intelligent use of the soil, one of our major natural resources.

This book has been written primarily for students of horticulture and agriculture in universities and colleges, who are embarking on their first and probably only course in soil science. It presents the modern views on the chemical and physical aspects of soils as the environment of plant roots on a molecular scale, together with an up-to-date evaluation of field soils and currently used growth media. The biological and biochemical aspects of soil science are not considered here in detail because of lack of space.

The book is in two parts. Part I, Basic Principles, starts with a discussion of the microstructure of soil materials, concentrating on the components of the finely divided (or clay) fraction, and continues with a description of the structure and properties of the microcrystalline clay minerals, the amorphous inorganic and organic soil materials and clay-organic complexes. This is followed by a discussion of the pore space, which contains soil water and soil air, and constitutes the molecular environment of roots. Soil water is in contact with and is replenished from the soil solid phase, and contains in ionic form the nutrients required by plants. The next chapter is a discussion of the ionic components in the environment of plant roots. Part II, Horticultural Principles, opens with a discussion of the macroscopic structure and composition of soils and other growth media. The management of soils is then discussed from the physical, chemical and biological points of view.

A book of limited size covering a wide field is necessarily selective; moreover, such selection is bound to be subjective to a certain extent. Attention has been concentrated on fundamental principles; these are presented critically where it was thought desirable. The authors have drawn on a large body of knowledge accumulated by many workers in the soil sciences whom it is impossible to acknowledge individually; most of those to whom the authors are indebted appear in the bibliography, where key references are listed together with suggestions for further reading. We are grateful to the Editor of the series, Professor L. Broadbent, for his interest and encouragement, and to our wives who have helped with the preparation of the manuscript. 